\title{
INVOLVEMENT OF METHYLTRANSFERASES ENZYMES DURING THE ENERGY METABOLISM OF THE ANAEROBIC ARCHAEON METHANOSARCINA SEMESIAE SP. NOV.
}

\author{
TJ Lyimo
}

Department of Molecular Biology and Biotechnology, Faculty of Science, University of Dar-esSalaam, P.O.Box 35179, Dar-es-Salaam, Tanzania: Email: Lyimo@amu.udsm.ac.tz

\begin{abstract}
The methyl group transfer from dimethylsulfide (DMS), trimethylamine and methanol to 2mercaptoethanesulfonic acid (coenzyme $M$ ) were investigated from cell extracts of Methanosarcina semesiae sp. nov. to evaluate whether the enzyme systems involved were constitutive or inductive. The extracts from cells grown on DMS exhibited methanogenic activity exclusively with DMS and methanethiol. Likewise when cells were pre-grown on trimethylamine or methanol the extracts only produced methane from the respective metaboilic substrate. Dimethylsulfide:methyl-coenzyme $M$ transferase activity was dependent on ATP, but hydrogen did not stimulate activity. The fact that ATP could be replaced by the reductant Ti(III)-citrate indicates that reductive activation of methyl transfer reaction in DMS conversion proceeds in a manner similar to methyltransferases involved in methanol and trimethylamine conversion, but with a different reduction source. This source appears to be limited since sometimes the cell extracts were totally inactive in the presence of ATP, while still being activated with Ti(III)-citrate. It was concluded that enzymes involved in methyl transfer reactions are specific for each substrate; DMS, trimethylamine and methanol and have to be induced. Further investigations are recommended to corroborate the current study.
\end{abstract}

\section{INTRODUCTION}

Methanosarcina semesiae sp. nov. is an obligately methylotrophic methanogenic archaeon which is able to grow on dimethylsulfide (DMS), methanethiol (MT), methanol and methylated amines (monomethylamine-MMA; DimethylamineDMA and trimethlamine-TMA) but not on acetate, formate or $\mathrm{H}_{2} / \mathrm{CO}_{2}$ (Lyimo et al. 2000). The $M$. semesiae was the first methanogenic archaeon isolated from Tanzanian mangrove sediment through enrichment with DMS. On a global scale, DMS is known to be the most important gas in sulfur cycle. Half of the estimated annual global sulfur flux of approximately 8 X $10^{7}$ tonnes comes from the ocean and about half of this is in the form of DMS (Dacey and Wakeham 1986, Ferek et al. 1986). DMS is produced in the marine environment primarily by degradation of the os moregulatory compound dimethylsulfoniopropionate

$\left[\left(\mathrm{CH}_{3}\right)_{2} \mathrm{~S}^{+} \mathrm{CH}_{2} \mathrm{COO}^{-}\right]$which is produced by algae and cyanobacteria (Dacey and
Wakeham 1986, Bürgmann et al. 2007). Anaerobic degradation of DMS $\left(\mathrm{CH}_{3} \mathrm{SCH}_{3}\right)$ and MT $\left(\mathrm{CH}_{3} \mathrm{SH}\right)$ has been ascribed to both methanogens and sulfate reducers (Lomans 1999). Sulfate reduction in marine sediments appeared to be the preferred route for DMS and MT degradation (Lyimo et al. 2002). However, methanogens also seemed to be involved. An immediate methane production was observed upon addition of DMS to sediments, and enrichment and isolation of a DMS and MT-utilizing methanogen, M. semesiae, was achieved. Many other DMS converting methanogens have been reported, mainly isolated from saline environments (Liu et al. 1990, Finster et al. 1992, Kadam et al. 1994, Ni et al. 1994).

The biochemical pathways by which DMS and MT are degraded by methanogens have not yet been elucidated. In the process of methanogenesis, three basic metabolic pathways may be distinguished, notably the conversion of $\mathrm{H}_{2}$ and $\mathrm{CO}_{2}$, of acetate and of 
methylated one carbon compounds (Daas 1996, Wassenaar 1999). Methanogenesis from methyl substrates is most extensively studied with the enzyme system converting methanol (Fig. 1). Available evidence suggests that other methylotrophic substrates like methylated sulfide and amines are metabolized by some modifications of the methanol pathway (Naumann et al. 1984, Tallant and Krzycki 1997, Wassenaar 1999).

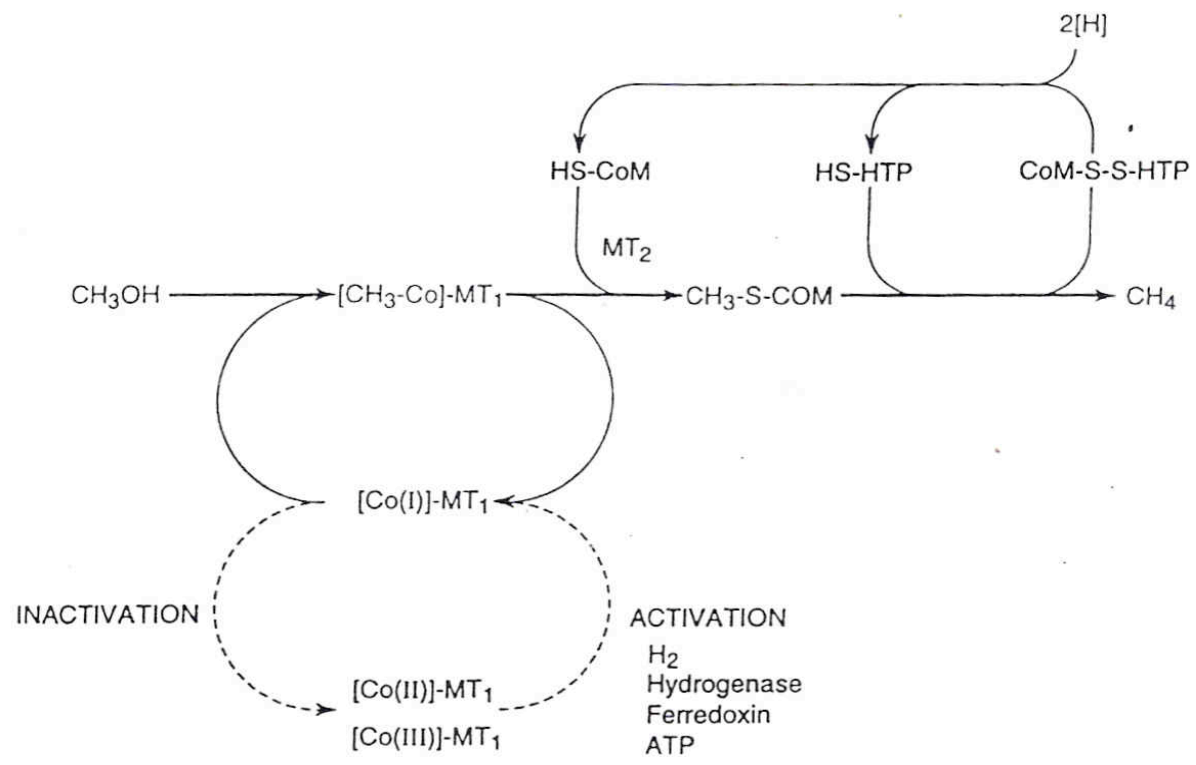

Figure 1: Scheme of methanogenesis from methanol. The cycle of activation-inactivation of methanol:5-hydroxybenzimidazolylcobamide methyltransferase $\left(\mathrm{MT}_{1}\right)$ is indicated by the dashed lines. $[\mathrm{Co}(\mathrm{III})],[\mathrm{Co}(\mathrm{II})]$, and $[\mathrm{Co}(\mathrm{I})]$ represent the various oxidation states of the cobalt of the corrinoid prosthetic groups of $\mathrm{MT}_{1}$. $\mathrm{MT}_{2}$, Co-methyl-5hydroxybenzimidazolylcobamide:coenzyme M methyltransferase; HS-CoM, coenzyme M; HS-HTP, 7-mercaptoheptanoylthreonine phosphate (Source: Daas 1996).

Reduction of methanol to methane proceeds via methyl coenzyme $\mathrm{M}$ ( $\left.\mathrm{CH}_{3}-\mathrm{S}-\mathrm{CoM}\right)$ which is synthesized from methanol and 2mercaptoethanesulfonic acid (HS-CoM) by the combined action of two methyltransferases (van der Meijden et al. 1983). The first methyltransferase, methanol:5-hydroxybenzimidazolcobamide $\left(\mathrm{B}_{12}-\mathrm{HBI}\right)$ methyltransferase $\left(\mathrm{MT}_{1}\right)$, cleaves the methyl group from the substrate and subsequently binds it to a prosthetic corrinoid. $\mathrm{MT}_{1}$ is a heterotrimetric enzyme composed of 49 and $24 \mathrm{kDa}$ subunits. The 49-kDa subunit contains a zinc atom that is involved in substrate cleavage (Sauer et al. 1997). The two 24-kDa subunits harbor the corrinoid prosthetic groups (Daas et al. 1993). Corrinoids are the basic structure of $\mathrm{B}_{12}$ compounds ( $\mathrm{Pol}$ et al. 1982). They contain cobalt atoms which may occur in 
three redox states, $\mathrm{Co}(\mathrm{III}), \mathrm{Co}(\mathrm{II})$ and $\mathrm{Co}(\mathrm{I})$. In order to accept the methyl group from methanol, the central cobalt atoms of the corrinoid prosthetic groups of $\mathrm{MT}_{1}$ must be present in the fully reduced $\mathrm{Co}(\mathrm{I})$ state (van der Meijden et al. 1983). To achieve and maintain this oxidation state, a reductive activation system consisting of hydrogenase, methyltranferase activating protein (MAP) and ATP is required (van der Meijden et al. 1983). In the next step the methyl group is transferred to HS-CoM by Co-methyl-5hydroxybenzimidazolyl-cobamide: HS-CoM methyl transferase $\left(\mathrm{MT}_{2}\right)$, to produce $\mathrm{CH}_{3}$-SCoM. In the final step of methanogenesis $\mathrm{CH}_{3}$-S-CoM is reduced to methane by the methyl-coenzyme M reductase system. The reduction of $\mathrm{CH}_{3}-\mathrm{S}-\mathrm{CoM}$ to methane is performed in a two-step reaction. In the first step, the reduction of $\mathrm{CH}_{3}$-S-CoM with 7mercaptoheptanoylthreonine phosphate (HSHTP) is catalyzed by methylcoenzyme M reductase, yielding methane and the heterodisulfide CoM-S-S-HTP. Next, CoMS-S-HTP is reduced at the expense of $\mathrm{H}_{2}$ by the membrane-bound enzyme heterodisulfide reductase to recover HS-CoM and HS-HTP (Heiden et al. 1993). In analogy to this model, for DMS, it is expected that the methyl groups of DMS are transferred to a specific methyltransferase $\left(\mathrm{MT}_{1}\right)$. Then the methyl groups are transferred to HS-CoM, by a second methyltransferase $\left(\mathrm{MT}_{2}\right)$.

Previous study using of $M$. semesiae culture suggested that enzymes involved in DMS, Methanol and TMA conversions have to be induced (Lyimo et al. 2000). This is confirmed in the present study with extracts of $M$. semesiae cells grown on DMS, TMA or methanol.

\section{MATERIALS AND METHODS Cell extracts}

Methanosarcina semesiae was grown at 30 ${ }^{\circ} \mathrm{C}$ in a 101 or 201 fermentor on mineral medium (Lyimo et al. 2000), containing methanol, TMA or DMS as the carbon and energy source. $80 \% \mathrm{~N}_{2} / 20 \% \mathrm{CO}_{2}$ was very slowly bubbled through the medium (about
$2 \mathrm{l} / \mathrm{h}$ ) at a low stirring speed $(100 \mathrm{rpm})$ to maintain anoxic environment. The inocula were pre-grown on the respective substrates for at least 5 transfers ( $5 \%$ inoculum). DMS was added in 3 portions to attain about 7 $\mathrm{mM}$ concentration to prevent possible growth inhibition. After 5 days the final optical density $\left(\mathrm{OD}_{600}\right)$ was 0.4 . Methanol or TMA was added twice at $10 \mathrm{mM}$ concentration resulting in an $\mathrm{OD}_{600}$ of 0.5 after 2 days.

Cells were harvested anaerobically at the end of growth in a continuous flow centrifuge. The cells were transferred to an anaerobic glove box $\left(98 \% \mathrm{~N}_{2} / 2 \% \mathrm{H}_{2}\right)$ and lysed by resuspending the cell pellet in anoxic water $(1 \mathrm{ml} / \mathrm{g})$. The lysed cells were two-fold diluted in $100 \quad \mathrm{mM} \quad N$-tris(hydroxymethyl)methyl-2-

aminoethanesulfonic acid (TES) buffer, $\mathrm{pH}$ 7, containing $30 \mathrm{mM} \mathrm{MgCl}, 2 \mathrm{mM}$ dithiothreitol, and DNAse $(0.1 \mathrm{mg} / \mathrm{ml})$ and centrifuged anaerobically at $40,000 \times \mathrm{g}$ (20 $\left.\min , 4^{\circ} \mathrm{C}\right)$. The supernatant referred to as cell free extract was collected in the anaerobic glove box and stored under $\mathrm{N}_{2}$ at $-80{ }^{\circ} \mathrm{C}$, until use.

\section{Enzyme assays}

Enzyme activities were measured in duplicate in $10 \mathrm{ml}$ serum bottles crimpsealed with grey butyl rubber stoppers. Reaction mixtures (final volume, $200 \mu \mathrm{l}$ ) were prepared in the anaerobic glove box and contained $25 \mathrm{mM} \mathrm{K}^{+}$-TES buffer (pH 7.0), $25 \mathrm{mM} \mathrm{MgCl}, 10 \mathrm{mM}$ HS-CoM, $2 \mathrm{mM}$ ATP or $5 \mathrm{mM} \mathrm{Ti(III)citrate,} \mathrm{and} 100 \mu \mathrm{l}$ cell extract (Wassenaar 1999). In some assays, 1 $\mathrm{mM}$ bromoethanesulfonic acid (BES) was added as a specific methanogenesis inhibitor. Glove box atmosphere $(2.5 \mathrm{ml})$ was added after sealing by use of a syringe to create overpressure. Bottles were incubated at $37^{\circ} \mathrm{C}$ and substrate $(10 \mathrm{mM}$, unless stated otherwise) was added by syringe to start the reaction.

Gas samples $(200 \mu \mathrm{l})$ for methane, DMS and MT analysis were taken by a pressure- 
lock syringe. For HS-CoM analysis, $15 \mu 1$ of the reaction mixture was withdrawn by a gas-tight syringe and added to $2 \mathrm{ml}$ of Ellman's reagent.

The concentration of HS-CoM was determined by mixing $15 \mu 1$ samples with 2 $\mathrm{ml}$ of $0.5 \mathrm{mM}$ 2,2'-dinitro-5,5'dithiobenzoic acid (Ellman's reagent [Ellman $1958]$ ) in $150 \mathrm{mM}$ Tris-HCl buffer (pH 8.0) and immediately measuring the absorbance at $412 \mathrm{~nm}$. A calibration curve was made with freshly prepared HS-CoM.

Protein concentrations were determined with Bio-Rad protein reagent (Bio-Rad laboratories) with bovine serum albumin as a standard (htpp://www.technomedica.com/ publikazii/belur/Bio-Rad.pdf).

Methane, DMS, and MT were analyzed by gas chromatography as described by Lomans et al. $(1997,1999)$.

\section{RESULTS AND DISCUSSION \\ Substrate specific enzymes}

The protein concentration of the Methanosarcina semesiae cell extracts was $35 \mathrm{mg} / \mathrm{ml}$ for DMS and $50 \mathrm{mg} / \mathrm{ml}$ for TMA and Methanol grown cells. Cell extracts of M. semesiae grown on DMS exhibited methanogenesis with DMS and MT as substrates (Fig. 2). Maximum activity on DMS was about 5 nmol. $\mathrm{CH}_{4} / \mathrm{min} / \mathrm{mg}$ protein. Methanol and TMA addition did not result in methanogenesis (Fig. 2) from cell extracts grown on DMS. It must be noted that during growth on DMS $M$. semesiae produce significant amount of MT as intermediate and vice versa, on MT it produces small amount of DMS (Lyimo et al. 2000). The result was there fore expected since when cell are grown on DMS, their extracts also showed activity with MT.

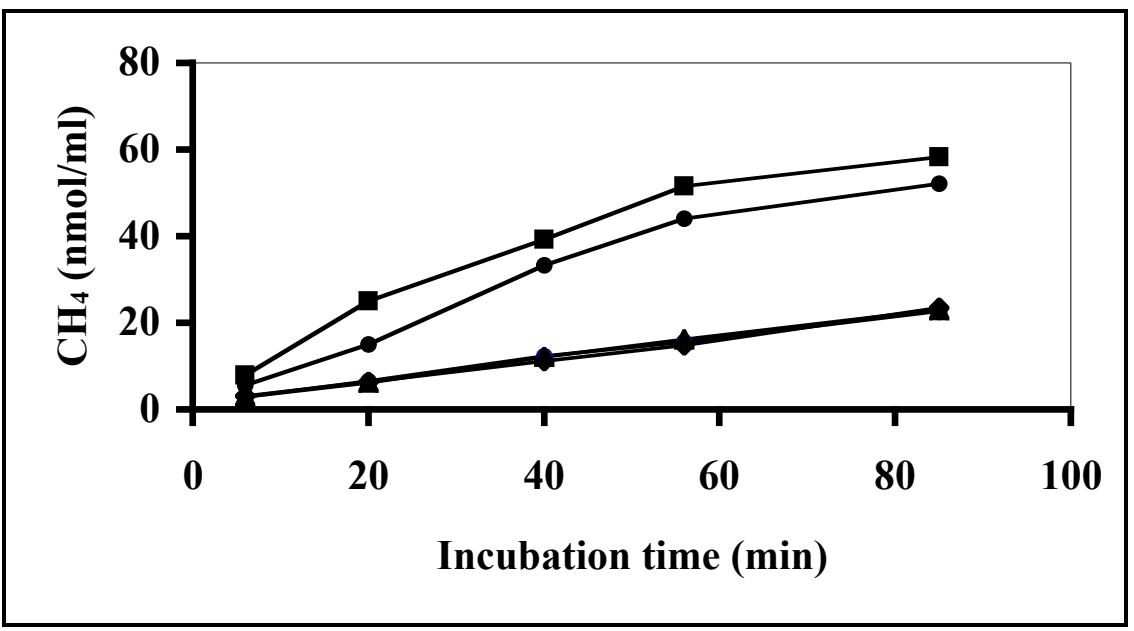

Figure 2: $\quad$ Methane production from cell extract (pre-grown on DMS) after addition of different

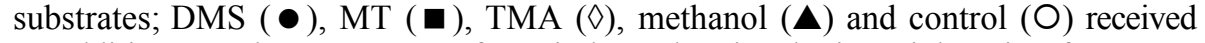
no additions. Values are mean of two independent incubation vials. Line for TMA, methanol and control overlapped. 


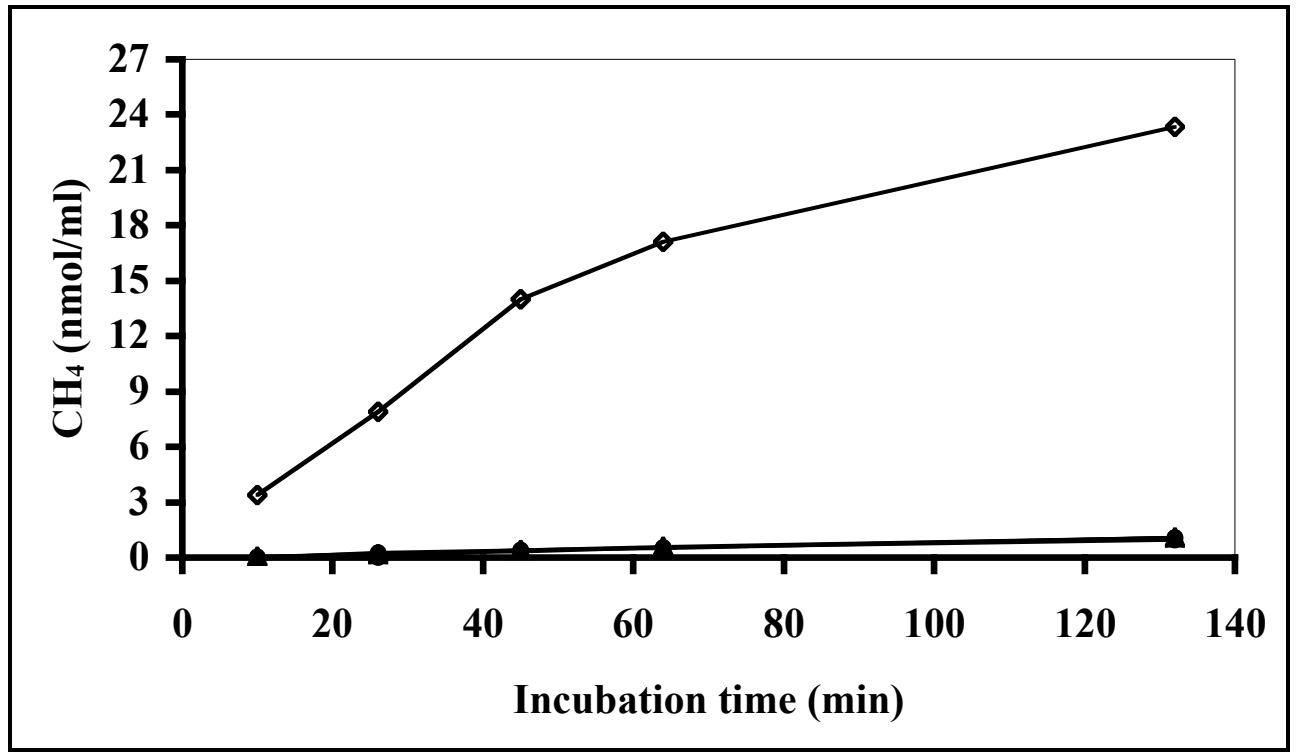

Figure 3: $\quad$ Methane production from cell extract (pregrown on TMA) after addition of different

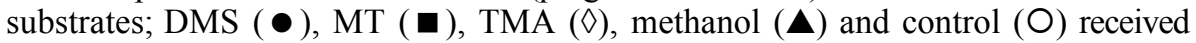
no additions. Values are mean of two independent incubation vials. (Note: Line for control, DMS, MT and methanol overlapped)

Likewise, M. semesiae cell extract grown on TMA showed methanogenesis exclusively when TMA was present $(1.3 \mathrm{nmol} / \mathrm{min} / \mathrm{mg}$ protein) (Fig. 3). This suggests that the enzyme involved in methyl transfer reactions were specific for each substrate, DMS, TMA and methanol, and have to be induced. This was supported by the results of the growth experiments showing lag-phases of days, when transferring cultures to a medium with another substrate (Lyimo et al. 2000). Similarly Ni and Boone (1993) showed that in cell-free extract of Methanolobus siciliae, the enzymes involved in degradation of DMS and MT are specific and inducible.

The history of cells seems to matter. When the inoculum for culturing DMS cells was pre-grown repeatedly on a mixture of DMS and methanol and finally on DMS only, the cell extract still exhibited relatively high methanogenesis with methanol (Fig. 4). It seems that complete repression of enzyme expression takes place after many generations. This is comparable to the observation by Ni and Boone (1993) in M. siciliae, that the lag phase after reverting to the initial substrate (DMS) gets longer when the exposure time (number of transfers) to a new substrate (TMA) increases.

\section{Stoichiometry}

When DMS consumption was compared with $\mathrm{CH}_{4}$ accumulation the ratio appeared to be $1: 1.5(+/-0.1)$. This means that in the cell extract the methanogenesis proceeds according the stoichiometry shown in eq. 1 for whole cells growing on DMS.

$2\left(\mathrm{CH}_{3}\right)_{2} \mathrm{~S}+2 \mathrm{H}_{2} \mathrm{O} \rightarrow 3 \mathrm{CH}_{4}+\mathrm{CO}_{2}+2 \mathrm{H}_{2} \mathrm{~S}$ (eq.1)

$\left(\mathrm{CH}_{3}\right)_{2} \mathrm{~S}+2 \mathrm{H}_{2} \rightarrow 2 \mathrm{CH}_{4}+\mathrm{H}_{2} \mathrm{~S}$ (eq.2)

During the incubations with cell extracts, $\mathrm{H}_{2}$ was present at low concentrations (about $2 \%$ from the anaerobic glove box) and changing the headspace for $100 \% \mathrm{H}_{2}$ or $\mathrm{N}_{2}$ did not influence the rate of methanogenesis. Therefore, hydrogen apparently cannot yield reduced cofactors needed in the $\mathrm{CH}_{3}$-S-CoM reductase reaction (reducing $\mathrm{CH}_{3}-\mathrm{S}-\mathrm{CoM}$ to 
methane) as was found during methanol conversion in the presence of hydrogen in M. barkeri or in Methanosphaera stadmaniae (Müller et al. 1986). In that case, one would expect to find a ratio of $1: 2$ for DMS conversion vs. $\mathrm{CH}_{4}$ production (eq. 2). Oxidation of methyl groups to $\mathrm{CO}_{2}$ obviously produces the electrons to reduce the cofactors. This shows that $M$. semesiae is strictly methylotrophic and that hydrogen does not stimulate growth nor does it influence methane production when the organism is growing on DMS (Lyimo et al. 2000). Interestingly, hydrogenotrophic methanogens growing on DMS have not yet been reported.

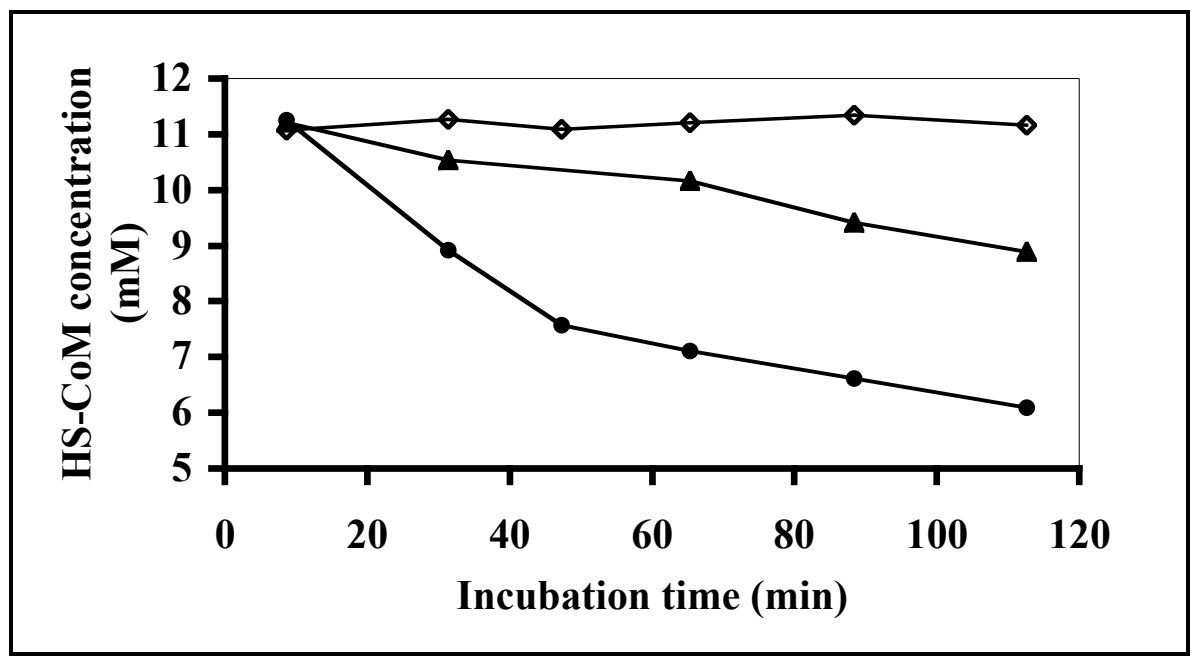

Figure 4: HS-CoM conversion from cell extract after addition of different substrates; DMS $((\bullet)$, TMA $(\diamond)$ and methanol $(\mathbf{\Delta})$. Cells were pre-grown repeatedly on a mixture of DMS and methanol and finally on DMS only (Values are mean of two independent incubation vials).

\section{Intermediates}

During methanogenesis from DMS, HSCoM levels in the extract remained constant (10 $\mathrm{mM})$, but when BES was added to inhibit the methyl-CoM reductase reaction, HS-CoM was consumed (Fig. 5). Results indicate that methanogenesis proceeds as found for methanol and TMA (Daas 1996, Wassenaar 1999), i.e. methyltransfer to HSCoM and subsequent reduction of the product $\mathrm{CH}_{3}-\mathrm{CoM}$ into methane (see Fig. 1). The HS-CoM consumption rate in the presence of BES exactly matched (1:1) with the methane production rate in the parallel incubation without BES (Fig. 5.). Obviously, $\mathrm{CH}_{3}-\mathrm{S}-\mathrm{CoM}$ formation is the rate-limiting step. In comparison, $\mathrm{Ni}$ and
Boone (1993) found $\mathrm{CH}_{3}-\mathrm{S}-\mathrm{CoM}$ reduction to be rate-limiting in their experiments with extracts of $M$. siciliae. MT evidently is an intermediate in DMS degradation. During DMS $(0.5-2 \mathrm{mM})$ conversion MT quickly accumulated to $10-100 \mu \mathrm{M}$. This corresponded with previous results that during growth on DMS, $M$. semesiae showed accumulation of low levels of intermediate MT (Lyimo et al. 2000). Similar results were reported for other methanogens growing on DMS (Finster et al. 1992, $\mathrm{Ni}$ and Boone 1993, Lomans et al. 1999). This seems to be analogous to TMA conversion by $M$. barkeri showing low levels of intermediary dimethylamine and monomethylamine by cells as well as 
extracts (Naumann et al. 1984). TMA is demethylated by three consecutive demethylating steps catalyzed by specific induced enzyme systems (Wassenaar 1999).
Whether DMS and MT are demethylated in $M$. semesiae by distinct specific enzymes remains to be investigated.

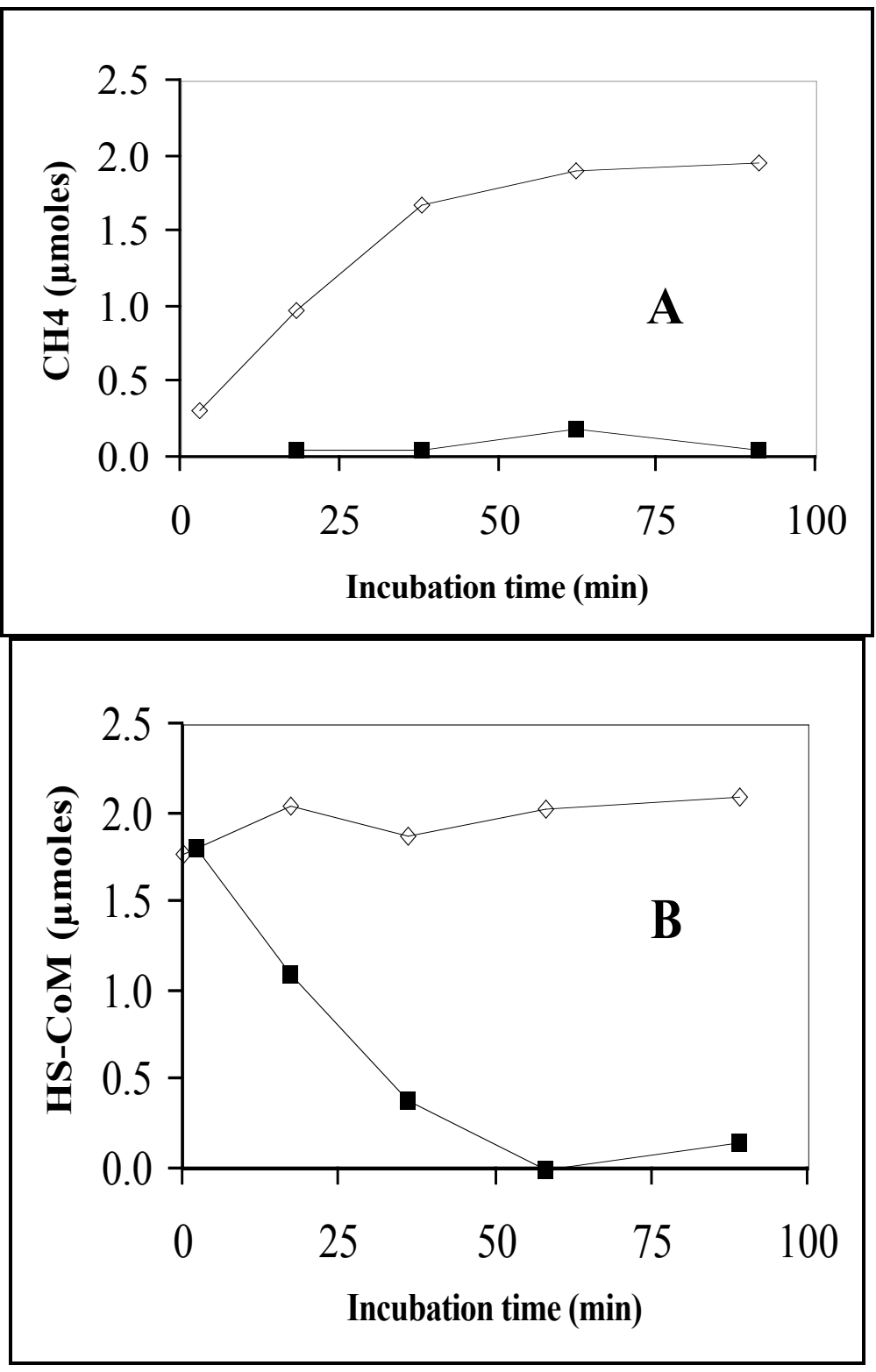

Fig. 5; $\quad$ Methane production (A) and HS-CoM consumption (B) by cell extract added with $\operatorname{BES}(\boldsymbol{\square})$ or without BES $(\diamond)$. The incubation vials for methane production and HSCoM assay were incubated in parallel. 


\section{Reductive activation}

Enzyme activity during methanogenesis was strictly dependent on the presence of ATP (i.e. without addition of ATP there were no activity). However, ATP could be replaced by a powerful artificial reducing agent Ti(III)-citrate and gave similar activities. This suggests that for DMS conversion reductive activation of the methyltranferase system is needed as described for $\mathrm{MT}_{1}$ in methanol and TMA conversion (Daas 1996, Wassenaar 1999). However, as mentioned, $\mathrm{H}_{2}$ did not stimulate methanogenisis nor the rate of $\mathrm{HS}-\mathrm{CoM}$ methylation (in the presence of BES-Figure 5) and so cannot be used to provide the electrons for this reductive activation. Another electron source seems to be present in the cell extracts. The fact that sometimes stimulation was only possible by $\mathrm{Ti}(\mathrm{III})$-citrate and not by ATP may point to a limited electron source, which is quickly exhausted by oxidation during storage of the extract. This may be related to the high sensitivity for storage and relatively low activities found (at least tenfold lower), as compared to extracts of $M$. barkeri (Daas 1996). Freezing and thawing of extract reduced the activity by $50 \%$ or more. Repeated freezing resulted in almost complete loss of methanogenic activity.

Although electrons for the reductive activation alternatively could be derived from the oxidation of methyl groups, this would need the presence of some active methyltransferase. The situation seems to be different in M. barkeri. While the organism does not grow on DMS, a specific methylthiol-CoM transferase is induced during growth on acetate (not on other substrates), which is active with DMS but hardly with MT. Although there was homology between one subunit of this enzyme and $\mathrm{MT}_{2}$, the molecular structure of this enzyme was quite different from the $\mathrm{MT}_{1} / \mathrm{MT}_{2}$ system of the other methylotrophic substrates and could not be reactivated by $\mathrm{ATP} / \mathrm{H}_{2}$ or Ti(III)-citrate (Tallant and Krzycki 1997).
It was concluded that methyltransferases enzymes involved in methyl transfer reactions are specific for each substrate; DMS, trimethylamine and methanol and were inducive. The fact that ATP could be replaced by the reductant $\mathrm{Ti}$ (III)-citrate indicates that reductive activation of methyl transfer reaction in DMS conversion proceed in the same way as methyltransferases involved in methanol and TMA conversion, but with a different reduction source. Further studies on the $M$. semesiae metabolism are recommended to corroborate the current findings.

\section{ACKNOWLEDGEMENT}

I would like to acknowledge the financial support from the Department of Microbiology, Radboud University Nijmegen(RUN), the Netherlands. I am also indebted to the University of Dar-es-Salaam for granting me a sabbatical leave in 2004. Mr. Bram Joosten and Bart Ackerschott, M.Sc. students at RUN, are thanked for their assistance in carrying out some experiments. I am also grateful to Drs. Arjan Pol and Huub J.M. Op den Camp for their guidence and comments that improved the earlier version of this manuscript. Annonymous reviwers are highly thanked for their constructive suggestions.

\section{REFERENCES}

Bürgmann H, Howard EC, Ye W, Sun F, Sun S, Napierala S and Moran MA 2007 Transcriptional response of Silicibacter $p o m e r r y i$ DSS-3 to dimethylsulfoniopropionate (DMSP). Environ. Microbiol. 9:2742-2755.

Daas PJH 1996 Methanol dependence methyl transfer reactions in Methanosarcina barkeri. Ph.D. Thesis, University of Nijmegen, The Netherlands.

Daas PJH,. Gerrits KAA, Keltjens JT, van der Drift C and Vogels GD 1993. Involvement of an activation protein in the methanol:2-mercaptoethanesulfonic acid methyltransferase reaction in 
Methanosarcina barkeri. J. Bacteriol. 175:1278-1283.

Dacey JWH and Wakeham SG 1986 Oceanic dimethyl-sulphide: Production during zooplankton grazing on phytoplankton. Science 233:1314-1316

Ellman GL 1958 A colometric method for determining low concentrations of mercaptans. Arch. Biochem. Biophys. 74:443-450.

Ferek RJ, Chartfield RB and Andreae MO 1986 Vertical distribution of dimethylsulfide in the marine atmosphere. Nature 320:514-516.

Finster K, Tanimoto Y and Bak F 1992 Fermentation of methanethiol and dimethylsulfide by a newly isolated methanogenic bacterium. Arch. Microbiol. 157:425-430.

Heiden S, Hedderich R, Setzke E and Thauer RK 1993 Purification of a cytochrome $b$ containing $\mathrm{H}_{2}$ :heterodisulfide oxidoreductase complex from membrane of Methanosarcina barkeri. Eur.J. Biochem. 213:529-535.

Htpp://www.technomedica.com/publikazii/b elur/Bio-Rad.pdf, Bio-Rad Protein Assay. Accessed 29/07/2008

Kadam PC, Ranade DR, Mandelco L and. Boone DR 1994 Isolation and characterization of Methanolobus bombayensis sp. nov., a methylotrophic methanogen that requires high concentrations of divalent cations. Int. J. Syst. Bacteriol. 44:603-607.

Liu Y, Boone DR and Choy C 1990 Methanohalophilus oregonense sp. nov., a methylotrophic methanogen from an alkaline saline aquifer. Int. J. Syst. Bacteriol. 40:111-116.

Lomans BP, Maas R, Luderer R, Op den Camp HJM, Pol A, van der Drift $\mathrm{C}$ and Vogels GD 1999 Isolation and c ha racteris a tion $\quad o f$ Methanomethylovorans hollandica gen. nov., sp. nov., a methylotrophic methanogen able to grow on dimethylsulfide and methanethiol isolated from freshwater sediment. Appl. Environ. Microbiol. 65:3641-3650.

Lomans BP, Smolders AJP, Intven LM, Pol A, OP den Camp HJM and van der Drift C 1997 Formation of Dimethyl sulfide and methanethiol in anoxic freshwater sediments. Appl. Environ. Microbiol. 63:4741-4747.

Lyimo TJ, Pol A, Op den Camp HJM 2002 Sulphate reduction and methanogenesis in Sediment of Mtoni Mangrove Forest Tanzania. Ambio 31:614-616.

Lyimo TJ, Pol A, Op den Camp HJM, Harhangi HR and Vogels GD 2000 Methanosarcina semesiae sp. Nov., a Dimethylsulfide-Utilizing Methanogen from Mangrove Sediment. International Journal of Systematic and Evolutionary Microbiology. 50:171-178.

Müller V, Blaut M and Gottschalk G 1986 Utilization of methanol plus hydrogen by Methanosarcina barkeri for methanogenesis and growth. Appl. Environ. Microbiol. 52:269-274.

Ni S and Boone DR 1993 Catabolism of dimethylsulfide and methane thiol by methylotrophic methanogens. p. 796810. In Oremland R.S. (ed.), Biogeochemistry of Global Change. New York: Chapman \& Hall.

Ni S, Woese CR, Aldrich HC and Boone DR 1994 Transfer of Methanolobus siciliae to the Genus Methanosarcina, naming it Methanosarcina siciliae, and emendation of the genus Methanosarcina. Int. J. Syst. Bacteriol. 44:357-359.

Naumann E, Fahlbusch K and Gottschalk G 1984 Presence of a trimethylamine:HScoenzyme $M$ methyltransferase in Methanosarcina barkeri. Arch. Microbiol. 138:79-83.

Pol A, van der Drift C and Vogels GD 1982 Corrinoids from Methanosarcina barkeri: structure of the -ligand. Biochem. Biophys. Res. Commun. 108:731-737.

Sauer K, Harms U and Thauer RK 1997 Methanol:coenzyme M methyltransferase from Methanosarcina barkeri. 
Purification properties and encoding genes of the corrinoid protein MT1. Eur. J. Biochem. 243:670-677.

Tallant TC and Krzycki JA 1997 Methylthiol:coenzyme M methyltransferase from Methanosarcina barkeri, an enzyme of methanogenesis from dimethylsulfide and methylmercaptopropionate. J. Bacteriol. 179:6902-691. van der Meijden P, Heythuysen HJ, Pouwels A, Houwen F, van der Drift C and Vogels GD 1983 Activation and inactivation of methanol:2mercaptoethanesulfonic acid methyltransferase from Methanosarcina barkeri. J. Bacteriol. 153:6-11.

Wassenaar RW 1999 Methanogenesis from methylamine in Methanosarcina barkeri Fusaro. Ph.D. Thesis, University of Nijmegen, The Netherlands. 